\title{
Research on the Effectiveness of Social Think Tanks - A Case of Center for China \& Globalization (CCG)
}

\author{
Pan $\mathrm{Xu}$ \\ School of Public Affairs, University of Science and Technology of China \\ No. 96, JinZhai Road, Baohe District, Hefei, Anhui, China \\ E-mail: xupan@mail.ustc.edu.cn
}

Received: February 24, 2017 Accepted: March 2, 2017 Published: March 6, 2017

doi:10.5296/jpmr.v3i1.10814ＵRL: http://dx.doi.org/10.5296/jpmr.v3i1.10814

\begin{abstract}
Social think tanks are an important part of the construction of new think tanks with Chinese characteristics and their effectiveness is an important influencing factor of the competitiveness of China's think tanks. The paper firstly analyzes the current situation of research on the problems relating to China's social think tanks, then constructs social think tank effectiveness evaluation indicator system from the four aspects of management effectiveness, influence effectiveness, diversity effectiveness and innovation effectiveness, lastly, it evaluates and analysis the effectiveness of Center for China \& Globalization (CCG) as an example, and offers the countermeasures and suggestions for improving its effectiveness.
\end{abstract}

Keywords: Social Think Tank; Effectiveness; Evaluation; Improvement

\section{Introduction}

In the critical period when China transforms and upgrades its economic development and its social contradictions are highlighted since the "Twelfth Five-Year Plan", the development of think tanks has been highly valued by the state. In Dec 2015, the Central Committee of the Communist Party of China held the working conference on the new think tanks with Chinese characteristics and introduced the methods of constructing high-end think tanks, and strengthening the construction of new think tanks with Chinese characteristics has been an important strategic measure to promote the national governance system and the governance capacity modernization.

Social think tanks, as an important part of the construction of new think tanks with Chinese characteristics, are currently still the weak link in the development of China's think tanks. Most of the current researches center on the characteristics and categories, and influence 
evaluation and development construction of the think tanks, lack the research on social think tanks, and even lack the evaluation of and research on the effectiveness of social think tanks, which restricts the effective development of social think tanks to a certain degree. Among the representative research reports of think tanks, such as The Global Go To Think Tank Index Report released by the University of Pennsylvania, Evaluation Report of Global Think Tanks released by Chinese Academy of Social Sciences (CASS), Report of China's Think Tanks released by Shanghai Academy of Social Sciences (SASS), Transparency Report of China's Think Tanks and Big Data Report of China's Think Tanks released by Tsinghua University, etc., the comprehensive influences of China's party, government and military think tanks are overwhelmingly dominant, and the social think tanks are obviously underdeveloped and significantly fall behind in comprehensive influence. Therefore, it is of very important realistic significance to analyze, research and improve the effectiveness of China's social think tanks.

\section{Related Theoretical Researches}

\subsection{Research on Think Tanks}

At present, the international academia has no uniform definition of think tanks, and scholars' different research perspectives of and focuses on think tanks influence their understanding of the concept of think tanks. The American scholar Paul Dickson (1971) thought that think tank were a kind of relatively independent and stable social organizations which researched public policies from the perspective of the independence of think tanks. The Canadian scholar Donald E Abelson (2002) thought that think tanks were the non-profit, non-partisan and neutral social organizations which researched public policies and management from the perspective of non-profit characteristic of think tanks.

Xu Lan and Zhu Xufeng (2006) thought that think tanks were relatively independent and stably-operated organization which researched social issues and corresponding policies and provided consultations. Pan Zhongqi (2010) believed that think tanks were the assistant organizations which analyzed and researched public policies and participated in making public policies, and thinks tanks in Europe were divided into professional ones which influenced government policies and university ones which focused on theoretical researches. $\mathrm{Xu}$ Xiaohu and Chen Qi (2012) emphasized that think tanks regarded public policies as the research object and the research on public policies as its main job responsibility, and provided professional consultations and services to decision-makers.

The current academia has no uniform standards regarding the classification of think tanks, just as the definition of the concept of think tanks. The American scholar James MaGann (2009) classified think tanks into six categories, respectively government-affiliated, party-affiliated, university-affiliated, semi-official, semi-independent and independent ones. Ma Jun (2012) classified think tanks into party, academic ones, advocating ones and contractual ones. By combining the domestic scholars' classification methods, the paper divides think tanks into official, semi-official, university and social ones. 


\subsection{Research on Social Think Tanks}

China's social think tanks are generally in the form of business entity or private non-business entity, besides being mainly engaged in the research on public policies, some of them are for the social demands, research the topics entrusted by governments, enterprises or individuals, and provide decision-making consultation services to the aforesaid three subjects. Compared with the official and semi-official think ones, social think tanks have distinct individualized characteristics.

In general, there are few researches on social think tanks both at home and abroad. Duan Zhezhe and Huang Weiren (2011) collated the development difficulties of China's social think tanks, and thought that the government should build relaxed and open social environment. Wang Dong (2013) believed that social think tanks were the indispensable part to realize the government decision-making scientification and democratization, and should pay attention to the relations between multiple subjects and the role positioning themselves in China' present environment. Qian Zaijian (2013) thought social think tanks rose necessarily from the perspective of the national and social relations, and required sounder legal and institutional guarantee to exert their functions. Jin Jiahou (2014) thought the domestic social think tanks should deal with the relations with government sectors well and develop together with official think tanks as its development strategy in the next stage.

In terms of case study on social think tanks, Wang Tian (2006) researched the development course and model of Unirule Institute of Economics, and thought China's social think tanks represented by Unirule should strive for the support from the governments, society and academia in the development process. Zhu Bei (2014) made the case study on Horizon Research Consultancy Group, systematically collated its growth course, made a detailed analysis on its social influence, and thought that social think tanks could improve their research competence only by strengthening the construction of their information systems.

\subsection{Research on Organizational Effectiveness}

The related research on organizational effectiveness is one of the hot issues of increasing concern in the organizational theories, organizational management and evaluation practices. In organizational theories, organizational effectiveness is the degree that an organization realizes its goals, and organizational goals reflect the reasons for the existence of the organization and consequences it seeks to achieve. According to the organizational effectiveness theories, the factors which influence the organizational effectiveness includes two aspects: internal and external factors. An organization is an open system and closely connected with the external environment, the external environment constitutes the opportunities and threats of an organization, therefore, the success of an organization depends on its interaction with the external environment to a great extent. The changes in external factors are often the main reasons that make an organization which was effective no more effective, and the internal factors include all the situations inside the organization.

Cohen and Bailey (1997) put forward the three aspects of organizational effectiveness: organizational performance, member attitudes and member behaviors. Cai Dezhang and 
Wang Yaowu (2007) proposed three suggestions on improving the organizational effectiveness: unity between thinking and method, unity between process and result, and unity between individual optimization and collective optimization. Effectiveness is a generalized concept, there exists a variation range between an organization and its departments, and effectiveness evaluation includes the realization degree of multiple goals. In an open system, organizational effectiveness constitutes the core contents of organizational development together with strategic management and external environment, and determines the goals, strategies and operation of an organization. It is the main responsibilities of the management team or leaders to help the organization adapt to the changed environment and better realize the organizational goals.

\section{Social Think Tank Effectiveness Evaluation Indicator System}

The social think tank effectiveness evaluation is comprehensive, complex and multi-layered. Organizational effectiveness determines the management effectiveness, the foundation of think tank organizational management is that a think tank coordinates its system, deeply understands and actively learns the missions under the moderately loose system control, and makes adaptive adjustment of the external environment. Based on it, management effectiveness is exerted. Therefore, social think tanks should firstly improve their organizational effectiveness in order to improve their core competitiveness and survivability.

\subsection{Establishment of the Evaluation System}

Through referring to the organizational effectiveness evaluation system, the characteristics of social think tanks, influencing factors of think tank organizational effectiveness, etc., and by combining the actual situations of China's social think tanks, the paper constructs China's social think tank effectiveness evaluation indicator system, establishes the first-class indicator system from the four aspects of management effectiveness, influence effectiveness, diversity effectiveness and innovation effectiveness, and the second-class indicator system based on the first-class indicator system, and finally adopts the evaluation indicator system composed by 4 first-class indicators and 16 second-class ones. The concrete indicators are as shown in Table 1 below.

Table 1. Social Think Tank Effectiveness Evaluation Indicators

\begin{tabular}{|c|c|c|}
\hline $\begin{array}{c}\text { First-class } \\
\text { Indicators }\end{array}$ & Second-class Indicators & Measurement Item \\
\hline \multirow{2}{*}{$\begin{array}{c}\text { B1 } \\
\text { Management } \\
\text { Effectiveness }\end{array}$} & $\begin{array}{c}\text { C11Definite organizational } \\
\text { objectives }\end{array}$ & $\begin{array}{c}\text { Can organizational goals guide the } \\
\text { organizational development } \\
\text { scientifically and effectively }\end{array}$ \\
\cline { 2 - 3 } & C12Standard governance structure & $\begin{array}{c}\text { Are board of supervision, council and } \\
\text { so on sound }\end{array}$ \\
\cline { 2 - 3 } & C13Perfect rules and regulations & $\begin{array}{c}\text { Are scientific and complete think tank } \\
\text { management rules available }\end{array}$ \\
\cline { 2 - 3 } & C14Transparent funds & Is funds use situation reasonable or \\
\hline
\end{tabular}




\begin{tabular}{|c|c|c|}
\hline & management & open \\
\hline \multirow{4}{*}{$\begin{array}{c}\text { B2 } \\
\text { Influence } \\
\text { Effectiveness }\end{array}$} & C21Decision-making influence & $\begin{array}{l}\text { The achievement approval levels and } \\
\text { times by the leaders at various levels }\end{array}$ \\
\hline & C22Academic influence & $\begin{array}{l}\text { The quantity and quality of published } \\
\text { works and papers }\end{array}$ \\
\hline & C23Media influence & The levels and times of media reports \\
\hline & C24International influence & $\begin{array}{l}\text { The cooperation levels and times with } \\
\text { foreign think tanks }\end{array}$ \\
\hline \multirow{4}{*}{$\begin{array}{c}\text { B3 } \\
\text { Diversity } \\
\text { Effectiveness }\end{array}$} & C31Diversified service modes & $\begin{array}{l}\text { The types and forms of external } \\
\text { services }\end{array}$ \\
\hline & C32Diversified fund sources & $\begin{array}{l}\text { The capital investment proportions } \\
\text { from the governments, enterprises, etc. }\end{array}$ \\
\hline & $\begin{array}{l}\text { C33Diversified performance } \\
\text { assessment }\end{array}$ & $\begin{array}{l}\text { Diversity of employee assessment } \\
\text { contents }\end{array}$ \\
\hline & C34Diversified risk control & $\begin{array}{l}\text { Risk measurement, evaluation and } \\
\text { consistency strategies }\end{array}$ \\
\hline \multirow{4}{*}{$\begin{array}{c}\text { B4 } \\
\text { Innovation } \\
\text { Effectiveness }\end{array}$} & $\begin{array}{l}\text { C41Informatization development } \\
\text { level }\end{array}$ & $\begin{array}{l}\text { The ability and degree of the Internet } \\
\text { application }\end{array}$ \\
\hline & $\begin{array}{l}\text { C42Intellectual property right } \\
\text { protection strength }\end{array}$ & $\begin{array}{c}\text { The ability and degree of intellectual } \\
\text { property right maintenance }\end{array}$ \\
\hline & $\begin{array}{l}\text { C43Employees' education } \\
\text { background }\end{array}$ & $\begin{array}{l}\text { The number and proportions of } \\
\text { employees with the doctoral degree, } \\
\text { master degree and bachelor degree }\end{array}$ \\
\hline & $\begin{array}{l}\text { C44Organizational innovation } \\
\text { atmosphere }\end{array}$ & Employees’ innovation intentions \\
\hline
\end{tabular}

Management effectiveness is the prerequisite and guarantee for the construction of the new think tanks with Chinese characteristics and includes the 4 second-class indicators of definite organization objectives, standard governance structure, perfect rules and regulations, and transparent funds management. Influence effectiveness is the survival and development path of China's social think tanks and includes the 4 second-class indicators of decision-making influence, academic influence, media influence and international influence. Diversity effectiveness is the foundation for China's think tanks with Chinese characteristics to form more objective and independent decision-making suggestions and includes the 4 second-class indicators of diversified service modes, diversified fund sources, diversified assessment contents and diversified risk control. Innovation effectiveness is one of the core indicators of social think tank effectiveness and includes the 4 second-class indicators of informatization development level, intellectual property right protection strength, employees' education background and organizational innovation atmosphere. 


\subsection{Weight Calculation}

AHP (Analytic Hierarchy Process) is an important hierarchical weight decision-making analysis method and often used for decision-making of multi-goal or complex issues. As multi-layered and multi-goal issues are involved in the think tank effectiveness analysis and evaluation, and it is necessary to obtain the weights of various indicators for the effective quantitative evaluation. After obtaining the expert score form in the Delphi Method, the paper calculates the weights of indicators at various levels rapidly and effectively in AHP.

While calculating the think tank effectiveness evaluation indicator system, the paper sets the four first-class indicators as the criterion layer, analyzes the correlations between various indicator factors in the consistent matrix method, forms the judgment matrix which is used to determine the relative importance of the indicators at various levels. Whether the think tank effectiveness judgment matrix is reasonable or not requires the consistency check. Through the consistency check, the consistency ratio of the judgment matrix is less than 0.1 , which shows that the judgment matrix is reasonable and the weight calculating results are reliable. The concrete weights are as shown in Table 2.

Table 2. Effectiveness Evaluation Indicators and Weights of Social Think Tanks

\begin{tabular}{|c|c|c|c|}
\hline First-Class Indicators & Weights & Secondary-Class Indicator & Weights \\
\hline \multirow{4}{*}{ B1 } & \multirow{4}{*}{0.072} & C11 & 0.0052 \\
\hline & & C12 & 0.0122 \\
\hline & & $\mathrm{C} 13$ & 0.0334 \\
\hline & & C14 & 0.0206 \\
\hline \multirow{4}{*}{ B2 } & \multirow{4}{*}{0.472} & C21 & 0.1595 \\
\hline & & C22 & 0.2261 \\
\hline & & C23 & 0.0505 \\
\hline & & $\mathrm{C} 24$ & 0.0359 \\
\hline \multirow{4}{*}{ B3 } & \multirow{4}{*}{0.170} & C31 & 0.0162 \\
\hline & & C32 & 0.0794 \\
\hline & & C33 & 0.0473 \\
\hline & & C34 & 0.0272 \\
\hline \multirow{4}{*}{ B4 } & \multirow{4}{*}{0.286} & C41 & 0.0800 \\
\hline & & $\mathrm{C} 42$ & 0.0389 \\
\hline & & $\mathrm{C} 43$ & 0.1344 \\
\hline & & C44 & 0.0326 \\
\hline
\end{tabular}




\subsection{Evaluation Grade Confirmation}

Effectiveness evaluation can be conducted to the concrete social think tanks according to the social think tank effectiveness evaluation indicator system. Experts are asked to rate the selected social think tanks at being very poor, poor, average, good and very good according to their effectiveness, and the concrete scores are set: 1 , very poor; 2 , poor; 3 ; average; 4 , good; and 5, very good. The final score of every indicator is obtained with the multiplication of the average score of the indicator by the weight coefficient, and the sum of the final scores of various indicators is the total effectiveness evaluation score of a selected social think tank. The full total score is 5, the lower the score is, the poorer the effectiveness is.

\section{Effectiveness Evaluation of CCG}

\subsection{Selection of Social Think Tank}

To select a typical and representative new social think tank, the paper emphatically considers about the following three aspects of: embodying the Chinese characteristics, having great influences and also taking into account high international horizon. After comprehensively considering about the aforesaid three aspects, the paper selects CCG (Center for China \& Globalization), ranking No. 1 among China's social think tanks in The 2015 Global Go To Think Tank Index Report released by The Think Tanks and Civil Societies Program (TTCSP) of the University of Pennsylvania as the effectiveness evaluation research object for analysis and research.

\subsection{Basic Information of CCG (Center for China \& Globalization)}

\subsubsection{Basic Information}

Center for China \& Globalization (Abbreviated as CCG) is a new think tank research institute composed by several research centers or institutes, it was established in 2008, headquarters in Beijing, and launches branches in Shanghai, Guangzhou, Qingdao, Shenzhen, Dongguan, etc, and overseas representative offices in Hong Kong, Washington, New York, London, Frankfurt, Paris, Sydney, etc. CCG is always specializing in the research fields of China's globalization strategies, enterprise internationalization, talent internationalization, etc., has nearly one hundred full-time think tank researchers and professionals, and is one of China's largest social think tanks.

\subsubsection{Organizational Structure}

CCG adopts the dual-committee model, namely, the Consultative Committee and the Academic Expert Committee, and the former is mainly responsible for the major matters inside CCG. The Consultative Committee adopts the council system and is composed by president, vice president, council director, managing director, directors, corporate directors, etc.

One highlighted advantage of CCG is its internationalized council. The Consultative Committee has the director and vice director who are responsible for the daily operation of CCG. CCG includes 11 internal organizations of No. One to No. Five Research Department, 
Editing Department, Strategy Planning Department, External Cooperation Department, Administrative and Financial Department, Human Resource Department and International Cooperation Department.

\subsubsection{Influence}

CCG keep close touch with The National People's Congress of the People's Republic of China (NPC), The National Committee of the Chinese People's Political Consultative Conference (CPPCC), Ministry of Human Resources and Social Security of the People's Republic of China (MOHRSS), the Organization Department of the Central Committee of the CPC, Ministry of Science and Technology of the People's Republic of China (MOST), National Development and Reform Commission (NDRC), the United Front Work Department of CPC Central Committee, Counselors' Office of the State Council of the People's Republic of China (COSC), China Center for International Economic Exchanges (CCIEE), All-China Federation of Returned Overseas Chinese, Western Returned Scholars Association (WRSA), etc., and actively provides the government sectors with independent and professional policy consultation and decision-making reports. At the same time, CCG has provided policy consultation services to the provincial-level and municipal-level governments of Beijing, Shanghai, Jiangsu, Guangdong, Zhejiang, etc. for many times.

In 2015, CCG took the lead in establishing the "One Belt and One Road Research Institute”, held the "One Belt and One Road” regional round-table forum periodically every month for consecutive eight months, and has formed persistent influence in the research field of "One Belt and One Road” strategies. CCG obtained remarkable achievements in proposing advice in 2015 and submitted over 60 Advice Proposing References, and over ten ones were commented and adopted by the central leaders and related ministries.

Every year, CCG publishes tens of research works both in Chinese and English, undertakes the tasks of many national ministries, holds several influential forums and think tank seminars, proposes opinions on related decision-making, influences the social consensus, and has been an excellent think tank in the research fields of talent internationalization, corporate internationalization, etc.

According to the world's most influential 2015 Global Go To Think Tank Index by the University of Pennsylvania Think Tank and Civil Society Program, CCG was comprehensively ranked 110th of the top think tanks worldwide, and one of the 100 top think tanks to watch for; ranked 7th among China's top-notch think tanks and No.1 among China's social think tanks.

\subsection{Effectiveness Evaluation of CCG}

The objective data of CCG are obtained according to the data on its website and the number of employees with high-level degrees, the number of papers published and commented by the superiors and also by retrieving related news reports in retrieval platforms. 10 experts are invited to evaluate the effectiveness of CCG and give scores according to the standard of being very poor, poor, average, good and very good (scored at 1, 2, 3, 4, and 5), and then the 
subjective data results are obtained. The effectiveness evaluation results of CCG are calculated by using the aforesaid data. The concrete results are as shown in Table 3 .

Table 3. Effectiveness Evaluation Results of CCG

\begin{tabular}{|c|c|c|c|c|}
\hline $\begin{array}{l}\text { First-class } \\
\text { Indicators }\end{array}$ & Second-class Indicators & $\begin{array}{l}\text { Average } \\
\text { Score }\end{array}$ & $\begin{array}{c}\text { Score of } \\
\text { Second-class } \\
\text { Indicators }\end{array}$ & $\begin{array}{c}\text { Score of } \\
\text { First-class } \\
\text { Indicators }\end{array}$ \\
\hline \multirow{4}{*}{$\begin{array}{c}\text { B1 } \\
\text { Management } \\
\text { Effectiveness }\end{array}$} & C11Definite organization objectives & 3.6 & 0.0187 & \multirow{4}{*}{0.2756} \\
\hline & C12Reasonable organizational structure & 4.2 & 0.0512 & \\
\hline & $\begin{array}{l}\text { C13Standard think tank articles of } \\
\text { association }\end{array}$ & 4.0 & 0.1336 & \\
\hline & C14Open funds use & 3.5 & 0.0721 & \\
\hline \multirow{4}{*}{$\begin{array}{c}\text { B2 } \\
\text { Influence } \\
\text { Effectiveness }\end{array}$} & C21Decision-making influence & 4.4 & 0.7018 & \multirow{4}{*}{2.0997} \\
\hline & C22Academic influence & 4.6 & 1.0400 & \\
\hline & C23Media influence & 4.1 & 0.2071 & \\
\hline & C24International influence & 4.2 & 0.1508 & \\
\hline \multirow{4}{*}{$\begin{array}{c}\text { B3 } \\
\text { Diversity } \\
\text { Effectiveness }\end{array}$} & C31Diversified service modes & 3.5 & 0.0567 & \multirow{4}{*}{0.6393} \\
\hline & C32Diversified fund sources & 3.9 & 0.3097 & \\
\hline & C33Diversified assessment modes & 3.7 & 0.1750 & \\
\hline & C34Diversified risk control & 3.6 & 0.0979 & \\
\hline \multirow{4}{*}{$\begin{array}{c}\text { B4 } \\
\text { Innovation } \\
\text { Effectiveness }\end{array}$} & C41Informatization development level & 4.0 & 0.3200 & \multirow{4}{*}{1.1753} \\
\hline & $\begin{array}{l}\text { C42Intellectual property right protection } \\
\text { strength }\end{array}$ & 3.6 & 0.1400 & \\
\hline & C43Employees' education background & 4.4 & 0.5914 & \\
\hline & $\begin{array}{c}\text { C44Organizational innovation } \\
\text { atmosphere }\end{array}$ & 3.8 & 0.1239 & \\
\hline
\end{tabular}

From Table 3, it can be known that CCG gets the highest scores in the two indicators of academic and decision-making influences among the 16 second-class indicators, because, on one and, the experts give higher scores, and on the other hand, their weights are higher.

Among the 4 first-class indicators, the score of management effectiveness is the lowest at 0.2756; and that of influence effectiveness is the highest at 2.0997. The effectiveness of CCG is scored 4.1899 totally (with the full score of 5), between being average and good, and is very high as a whole. From the experts' scoring situation, the average expert score is 3.9438, between being average and good, and is and very close to being good, thus it can be seen that 
experts highly value the overall effectiveness of CCG. As the total score is higher than the average expert score, it can be seen that experts highly score the indicators with higher weights, such as academic influence, decision-making influence, employees' education background, etc., and the expert scores are higher than the average score, which, from another aspect, reflects that CCG performs well in important effectiveness influencing indicators.

\section{Countermeasures and Suggestions on Improving the Effectiveness of CCG}

Through theoretical analysis and by combining the current development situation of China's social think tanks and the actual effectiveness evaluation of CCG, it is believed that the effectiveness of CCG can be improved from the following aspects:

\subsection{Pinpoint the Goal Positioning and Conduct Differentiated Development}

Social think tanks are generally small in scale, and will get into disadvantageous situation of blind development if they have no explicit positioning and pursue large-scale and comprehensive development. To be characteristic and constantly strong in fierce competition, they should develop towards the professional and characteristic directions. They should pinpoint the function positioning and conduct dislocation development according to their own characteristics and advantages. CCG, based on analyzing its characteristics and advantages, should form its unique competitive advantages and build its core competitiveness and sustainable advantages by concentrating its resources. As CCG's tenet is: proposing advice for China with the global horizon; and providing suggestions for the globe with China's wisdom; and its vision is: to build the international think tank with the international influence. Therefore, we can know that the positioning and core competitiveness of CCG lie in its globalization and professionalization. Thus, its development and layout should be based on the globe and launch its branches in important countries or regions around the world. At the same time, it should focus on political and economic researches, but few or not get involved in non-main research directions, such as military, diplomatic, etc.

\subsection{Sustainably Improve Its Influences, Especially the Academic and Decision-making Influences}

The influence effectiveness indicators witness the highest scores, and the scores of influence effectiveness, especially the score of academic effectiveness, determine the effectiveness level of the think tanks to a certain degree. CCG has higher scores in influence effectiveness, being manifested by its solid research ability and good academic influence. CCG should constantly improve its professional ability by using academic resources to keep its influence advantage. CCG can make academic researches and apply for important subjects through holding academic forums and cooperating with well-known think tanks and academic institutions at home and abroad, or conduct special researches by establishing internal organizations or academic groups, for example, CCG One Belt and One Road Research Institute and other internal special research institutions have formed several substantial research achievements. At the same time, CCG can also make full use of its political resources to promote its political influence, for example, it can actively conduct cooperative 
researches with party departments, invite the academic people from the political circles to join or participate in its subjects or projects.

\subsection{Strengthen Open Operation Models and Strive for Diversified Fund Sources}

To improve its effectiveness, CCG should further strengthen the open operation models. On one hand, it should absorb outstanding talents from all over the world to make researches in full-time or part-time manner, on the other hand, it should extensively communicate with the external academic institutions, think tanks, etc., which can not only strengthen its research vitality but also bring new research thoughts. CCG should pay attention to the international hot issue more extensively and accelerate its development and progress. At the same time, CCG should strive for diversified fund sources to keep normal researches and also the research independence. Compared with foreign ones, China's social think tanks just have simplex fund sources currently. CCG should make a try and exploration in terms of fundraising mechanism and constantly absorb various kinds of external funds to ensure the fund source diversity and prevent the research achievements from being greatly influenced by sponsors or a certain single investor.

\subsection{Improve the Think Tank Members' Quality, and Enhance the Internal Management Level}

From the expert score form, it can be seen that CCG's employee quality is highly evaluated, but unlike the party, government and military ones, China's social think tanks have low overall quality and knowledge levels and also lack in-system guarantees and glory. Think tanks are research institutions, and the level of their research achievements depends on their members' quality and competence, and high-quality researchers play decisive roles. In order to improve the members' quality, on one hand, think tanks can train talents together with universities and scientific research institutions at home and abroad. At present, CCG has cooperated with Beijing Normal University (BNU), Southwestern University of Finance and Economics (SWUFE), and Capital University of Economics and Business (CUEB) to recruit $\mathrm{PhD}$ students all over China, and should strengthen the talent training strength and width in the future; on the other hand, CCG can attract talents through competitive market-oriented compensation and international practice and communication. Besides, the improvement of internal management level is also an important measure to improve the effectiveness of CCG, on one hand, it should construct the modern organizational structure and form fully-functional and efficiently-operated organization system, on the other hand, it should boost its transparency and publicize the related information periodically to strive for the support and trust from governments, related social institutions and customers.

\section{References}

Chen, S., \& Meng, M. (2015). Study on the Mechanism of the Impacts and Think Tanks Influence: Based on the Empirical Research on 39 Samples of Chinese Think Tanks. Studies in Science of Science, 9, 1305-1312.

Deng, R. H. (2003). Organizational Effectiveness Research and Application Significance for Enterprises in China. Science Research Management, 5, 98-102. 
Jin, Jiahou. (2014). Development of Non-Governmental Think Tanks: Status Quo, Logic and Mechanism. Administrative Tribune, 1, 56-61.

Leeson, P. T., Ryan, M. E., \& Williamson, C.R. (2012). Think tanks. Journal of Comparative Economics, 40(1), 62-77.

Li, Qiaomei. (2013). The Nurture and Development of Non-Governmental Think Tanks in China. Chongqing Social Sciences, 8, 111-116.

Li, Wentao. (2009). Analysis on the Current Situation of China's Non-Governmental Think Tanks and Suggestions for Its Development. Market Modernization, 5, 196-197.

Li, Y. (2015). Think tank 2.0 for deliberative policy analysis. Policy Sciences, 48, 25-50.

Wang, H. (2014). Thoughts and Practice of Chinese Think Tank Internationalization. Chinese Public Administration, 5, 20-24.

Weidenbaum, M. (2010). Measuring the Influence of Think Tanks. Society, 47(2), 134-137.

Wiarda, H. J. (2015).Think tanks and foreign policy in a globalized world: New ideas, new “tanks,” new directions. Canada’s Journal of Global Policy Analysis, 70(4), 517-525.

Xu, Xiaohu, \& Chen, Qi. (2012). Research on Basic Problems of China’s Think Tanks. Academic Forum, 11, 178-184.

Ye, Linfeng. (2016). Several Suggestions for Constructing New Think Tanks with Chinese Characteristics. Journal of Intelligence, 3, 32-35.

\section{Copyright Disclaimer}

Copyright for this article is retained by the author(s), with first publication rights granted to the journal.

This is an open-access article distributed under the terms and conditions of the Creative Commons Attribution license (http://creativecommons.org/licenses/by/3.0/). 